\title{
Effects of Green Tea Use on Wound Healing
}

\author{
Efectos del Uso del Té Verde sobre la Cicatrización
}

\author{
"Ana Luiza de Almeida Neves; *"Marilena Chinali Komesu \& *"Miguel Angel Sala Di Matteo
}

NEVES, A. L. A.; KOMESU, M. C. \& DI MATTEO, M. A. S. Effects of green tea use on wound healing. Int. J. Morphol., 28(3):905$910,2010$.

SUMMARY: Green tea, a product from Camellia sinensis, consists of over 200 componentes. The most known are the catechins, ou polyphenolic compounds, or flavonoids, but it contains also polysacharide conjugates, amino acids, caffeine and vitamins. Studies have suggested that the regular consumption of green tea reduces the risk of cancer, protecting agains initial events and progression of the disease, may act as antioxidant, has bactericidal properties, and that green tea consumption may be an adjuvant in the treatment of diabetes mellitus, hypertension and hypercholesterolemia. Our experimental study was carried out with male Wistar rats, separated in two groups, experimental and control. The animals in control group were given water ad libitum, and the animals in the experimental group received green tea instead of water. After 2 weeks of experimental period, all the animals, suffered surgical wounds on the dorsum. The animals were sacrificed on 1, 3 and 7 days after surgery. Skin samples were used for light microscopy evaluation. Our results allowed us to observe that the experimental group (green tea drinking) presented accelerated epithelial neformation on day 3 after surgery, when epithelial neoformation is in the initial phases. The surgical areas presented $48.20 \% \mathrm{X} 27.32 \%$ epithelial neoformation for green tea group and their controls respectivelly at this time. The results of the present study, along with other information about green tea in the literature, strongly suggests that regular use of green tea may be beneficial in surgery situations, when fast epithelial neoformation is desirable.

KEY WORDS: Green tea; Wound healing; Wistar Rat.

\section{INTRODUCTION}

Green tea, a product from Camellia sinensis, consists of over 200 componentes. The best known are the catechins, or flavonoids, or polyphenolic compounds, but it contains also polysacharide conjugates (TPCs), amino acids, caffeine and vitamins (Fujihara et al., 2007; Monobe et al., 2008; Chen et al., 2009).

The flavinol polyphenolic compounds are the most abundant, accounting for nearly $30 \%$ of the dry weight of the green tea leaves. The flavonoides, polyphenols or catechins, include the epicatechin (EC), epigallocatechin (EGC), epicatechin-3-gallate (ECG) and epigallocatechin3-gallate (EGCG) (Mukhtar \& Ahmad, 1999; Chen et al., 2002). Tea polysaccharides conjugates (TPCs) seems to contribute to immunogogical irradiation protection, antiblood coagulation, also have anticancer action, antioxidant actions, anti-HIV protection, the ability to inhibit popathogenic bacterial adhesion, and hypoglycemic activities (Fujihara et al.; Monobe et al.).
Different tipes of tea preparations are originate from Camellia sinensis, by different processing methods. The three most popular tea types are black tea, $( \pm 78 \%$, well fermented, mainly consumed in Western and some Asian countries), green tea $( \pm 20 \%$, unfermented, mainly consumed in Asia and a few other countries), and oolong tea $( \pm 2 \%$, semifermented, consumed only in Asia). The plant Camellia sinensis was originally discovered in Southeast Asia thousands of years ago, and Chinese mythology says that the emperor Shen Nung discovered the tea for the first time in $2737 \mathrm{BC}$. Tea is currently used in at least 30 countries around the world (Mukhtar \& Ahmad; Fijihara et al.).

The history of the medical effects on green tea starts on the early eighth century with the Buddhist monks who recognized green tea for its medicinal powers, but nowadays there is also an increasing interest in the beneficial effects of green tea on health and disease prevention (Chen et al., 2002).

* Post Graduation Program, School of Dentistry at Ribeirão Preto, University of São Paulo, Brazil.

** Department of Morphology, Stomatology and Physiology, School of Dentistry at Ribeirão Preto, University of São Paulo, Brazil. 
Studies have suggested that the regular consumption of green tea reduces the risk of cancer, protecting against initial events and progression of the disease (Mukhtar \& Ahmad), that green tea may act as an antioxidant, has bactericidal properties, its consumption may be an adjuvant in the treatment of diabetes mellitus, hypertension and hypercholesterolemia (Chen et al., 2002).

Green tea has the ability to sequester metal ions and scavenge reactive oxygen species, studies showed that green tea may several proteins involved in inflammation, including lipogenase, cyclooxygenase, nitric oxide synthase, tumor necrosis factor-a, xanthine oxidase, and nuclear factor $\mathrm{kB}$ (NFkB), so as to modulate inflammation associated signals (Chen et al., 2002) and that EGCG seems to be the most anti-cancer protective agent (Mukhtar \& Ahmad).

Possible mechanisms of action of green tea are: for anticancer activity:

Green tea polyphenols may activate the mitogenactivated protein kinase (MAPK) pathway, by inhibiton of enzymes such as the cytocromes P450 which are involved in the bio-activation of carcinogens (Yu et al., 1997).

Some studies have shown that green tea is involved in phase II detoxification, based on the antioxicant action (Mukhtar \& Ahmad).

Green tea inhibits utokinase activity, which is one of the most frequently expressed enzymes in human cancers (Jankun et al., 1997).

Green tea inhibits tumor promoter-mediated activator protein (AP-1) avoiding activation and cell transformation, which plays an important role in tumor promotion (Mukhtar \& Ahmad).

Green tea induces apoptosis, mostly in already induced carcinomas (Ahmad et al., 1997; Fujiki, 1998; Yang et al., 1999).

Green tea inhibits cellular proliferation and tumor progression via epidermal growth factor receptor (EGFR) pathway, and may exert its tumor growth-inhitory effects via VEGF-VEGFR axis, avoiding enough blood supply to the neoplastic cells (Shirakami et al., 2009).

And other effects of green tea use may be:

Green tea inhibits the induction of nitric oxide (NO)synthase via a down-regulation in the transcription of nuclear factor-kB (NF-kB), and since NF-kB acts as a master switch or control point for the expression of a large number of proinflammatory genes, EGCG may act modulating inflammatory process (Chen et al., 2002).

\section{MATERIAL AND METHOD}

The experiment was carried out with male Wistar rats, weigh $150-180 \mathrm{~g}$ at the begining of the experimental procedures. All the animals were obtainned from the Central Animal House at Ribeirão Preto Campus of the University of São Paulo, Brazil. The animals were housed five to a polypropylene cage and were provided food ad libitum. All the animals were maintained under controlled conditions of temperature $\left(23-25^{\circ} \mathrm{C}\right)$ and a light/dark ciclus of 12 hours.

The animals were randomized into experimental and control groups (15 animals each). To animals in control group were served water ad libitum. To all animals in experimental group received green tea instead of water. Green tea leaves were added to boiling water (according to manufacturer) and steeped for 10 minutes, then the mixture was filtered and offered to the experimental animals instead of water.

After 2 weeks of experiment, all the animals, in the control and experimental groups, received surgical procedures as follow. Under tribromoethanol anesthesia, the back of all rats were shaved and skin wounds $(4 \mathrm{~mm}$ diameter wounds, each side of the median line, aproximately $2 \mathrm{~cm}$ from each other) were prepared, as a modificated method from Mustoe et al. (1987), Whitby \& Ferguson (1991), and Most et al. (1996). Povidone-iodine was used as antiseptic.

Animals were sacrifed 3 and 7 days after surgery. For the sacrifice, the animals were anesthetized again with tribromoethanol (2,2,2 tribromoethanol Aldrich, $25 \mathrm{mg} / 100 \mathrm{~g}$ body weight i.p.). While anesthetized, the abdominal cavity was oppened and the animals were sacrificed by cardiorespiratory breakdown.

The skin samples were excised (skin with surgery areas), fixed in $10 \%$ formalin solution (24 hours) and processed for paraffin embedding procedures. Parafin embedded sections $(6 \mu \mathrm{m}$ thick) were cut perpendicular to the wound surface, mounted onto slides, and stained with hematoxilin and eosin (H\&E) for light microscopy evaluation.

For wound healing evaluation, edema area, cellular containing tissue, and epithelial neoformation were observed 
by counting points (10 selected marked points on a grade, counting 10 areas $=100$ points, a modification of Chalkley method) (Chalkley, 1943) and comparison among groups (relative percentage of counted points). Ten randomly selected wound-healing areas $\left(182 \mathrm{~mm}^{2}\right)$ were evaluated for each animal. The collected data were statistically analysed using the Mann Whitney U test for comparison between two samples. $\mathrm{P}[\mathrm{U}]$ values $\leq 0.05$ were considered statistically significant.

The study protocol was reviewed and approved by the University of São Paulo - Campus of Ribeirão Preto Ethical Committee for the Experimental Animal Use.

\section{RESULTS AND DISCUSSION}

Table I sumarizes the percent of points on epithelial neoformation on days 1, 3 and 7 post-surgical procesures.
The most noted differences were observed on day 3 after surgery, during the inicial healing process period, and green tea group had accelerated epithelial neformation. By the end of the healing process we did not observe important differences between control and experimental groups for epithelial covering of the surgical area.

Table II shows the percent of points counted in healing area. Points on edema, blood vessels and cells present in tissue, were counted.

According to our results, green tea use is associated with diminished edema $(31.80 \%$ X $20.40 \%$ on day 3 , and $16.16 \% \mathrm{X} 0.75 \%$ on day 7 post surgery) and increased cellular content $(57.40 \%$ X $69.40 \%$ on day 3 and $80.76 \%$ X $94.51 \%$ on day 7 post surgery) on wound healing area.

Green tea is a popularly consumed beverage now a days, relatively inexpensive and non-toxic, and most importantly, has been shown to give protection agains many diseases and complications. Even though a complete

Table I. Percent of points on epithelium and pseudomembrane (Pseudom.) on wound areas in control and experimental animals ( 7 days of green tea). The evaluations were made on days 1, 3 and 7 after surgery.

\begin{tabular}{|c|c|c|c|c|c|}
\hline \multicolumn{2}{|c|}{ DAY 1} & \multicolumn{2}{|c|}{ DAY 3} & \multicolumn{2}{|c|}{ DAY 7} \\
\hline Epithelium & Pseudom. & Epithelium & Pseudom. & Epithelium & Pseudom. \\
\hline \multicolumn{6}{|c|}{ CONTROL } \\
\hline $0 \%$ & $100 \%$ & $24,17 \%$ & $75,83 \%$ & $69.98 \%$ & $30.02 \%$ \\
\hline $0 \%$ & $100 \%$ & $19.85 \%$ & $80.15 \%$ & $100 \%$ & $0 \%$ \\
\hline $0 \%$ & $100 \%$ & $36.39 \%$ & $63.61 \%$ & $62.85 \%$ & $37.50 \%$ \\
\hline $0 \%$ & $100 \%$ & $26.73 \%$ & $73.27 \%$ & $100 \%$ & $0 \%$ \\
\hline $0 \%$ & $100 \%$ & $31.48 \%$ & $68.53 \%$ & $100 \%$ & $0 \%$ \\
\hline $0 \%$ & $100 \%$ & $27.32 \% \pm 6.55$ & $72.28 \% \pm 6.42$ & $86,57 \% \pm 18.56$ & $13,50 \% \pm 18.69$ \\
\hline \multicolumn{6}{|c|}{7 DAYS GREEN TEA } \\
\hline $0 \%$ & $100 \%$ & $47.00 \%$ & $53.00 \%$ & $69,00 \%$ & $31,00 \%$ \\
\hline $0 \%$ & $100 \%$ & $42.00 \%$ & $58.00 \%$ & $100 \%$ & $0 \%$ \\
\hline $0 \%$ & $100 \%$ & $48.00 \%$ & $52.00 \%$ & $55,00 \%$ & $45.00 \%$ \\
\hline $0 \%$ & $100 \%$ & $56.00 \%$ & $44.00 \%$ & $100 \%$ & $0 \%$ \\
\hline $0 \%$ & $100 \%$ & $48.00 \%$ & $52.00 \%$ & $100 \%$ & $0 \%$ \\
\hline $0 \%$ & $100 \%$ & $48.20 \% \pm 5.02$ & $51.80 \% \pm 5.02$ & $84.80 \% \pm 21.39$ & $15.20 \% \pm 21.39$ \\
\hline & & $\mathrm{u}$ & $\mathrm{v}$ & & \\
\hline \multicolumn{6}{|c|}{ MANN WHITNEY U TEST } \\
\hline $\mathrm{U}$ calc $=12.5$ & $\mathrm{U}$ calc $=12.5$ & $\mathrm{U}$ calc $=0 * *$ & $\mathrm{U}$ calc $=0^{* *}$ & $\mathrm{U}$ calc $=11.5$ & $\mathrm{U}$ calc $=11.5$ \\
\hline $\mathrm{P}[\mathrm{U}[=0.5000$ & $\mathrm{P}[\mathrm{U}[=0.5000$ & $\mathrm{P}[\mathrm{U}[=0,004$ & $\mathrm{P}[\mathrm{U}[=0.004$ & $\mathrm{P}[\mathrm{U}[=0.421$ & $\mathrm{P}[\mathrm{U}[=0.421$ \\
\hline
\end{tabular}

** - Significant for a $\leq 0.01$. 
NEVES, A. L. A.; KOMESU, M. C. \& DI MATTEO, M. A. S. Effects of green tea use on wound healing. Int. J. Morphol., 28(3):899-904, 2010.

Table II. Percent of points on wound healing area edema, blood vessels and cellular content) in control and experimental animals.

\begin{tabular}{|c|c|c|c|c|c|}
\hline \multicolumn{2}{|c|}{$\%$ POINTS ON EDEMA } & \multicolumn{2}{|c|}{ \% POITS ON BLOOD VESSELS } & \multicolumn{2}{|c|}{$\%$ POINTS ON CELLS } \\
\hline Control & Green tea & Control & Green tea & Control & Green tea \\
\hline \multicolumn{6}{|c|}{ DAY 1 AFTER SURGERY } \\
\hline $20.00 \%$ & $26.00 \%$ & $10.00 \%$ & $12.00 \%$ & $60.00 \%$ & $52.00 \%$ \\
\hline $23.40 \%$ & $35.00 \%$ & $11.00 \%$ & $10.00 \%$ & $65.60 \%$ & $55.00 \%$ \\
\hline $27.20 \%$ & $29.00 \%$ & $9.00 \%$ & $12.00 \%$ & $63.80 \%$ & $59.00 \%$ \\
\hline $26.20 \%$ & $32.00 \%$ & $12.00 \%$ & $11.00 \%$ & $61.30 \%$ & $57.00 \%$ \\
\hline $24.00 \%$ & $33.00 \%$ & $12.00 \%$ & $12.00 \%$ & $64.00 \%$ & $55.00 \%$ \\
\hline $24.16 \% \pm 2.79$ & $31.00 \% \pm 3.56$ & $10.80 \% \pm 1.30$ & $11.40 \% \pm 0.89$ & $63.04 \% \pm 2.16$ & $55.60 \% \pm 2.61$ \\
\hline \multicolumn{6}{|c|}{ MANN WHITNEY U TEST } \\
\hline \multicolumn{2}{|c|}{$\mathrm{U}$ calc $=2 *$} & \multicolumn{2}{|c|}{$\mathrm{U}$ calc $=9$} & \multicolumn{2}{|c|}{$\mathrm{U}$ calc $=0 * *$} \\
\hline \multicolumn{2}{|c|}{$\mathrm{P}[\mathrm{u}]=0.016$} & \multicolumn{2}{|c|}{$\mathrm{P}[\mathrm{u}]=$} & \multicolumn{2}{|c|}{$\mathrm{P}[\mathrm{u}]=0.004$} \\
\hline \multicolumn{6}{|c|}{ DAY 3 AFTER SURGERY } \\
\hline $24.00 \%$ & $17.00 \%$ & $11.00 \%$ & $12.00 \%$ & $65.00 \%$ & $71.00 \%$ \\
\hline $26.00 \%$ & $25.00 \%$ & $14.00 \%$ & $10.00 \%$ & $60.00 \%$ & $65.00 \%$ \\
\hline $33.00 \%$ & $20.00 \%$ & $10.00 \%$ & $7.00 \%$ & $57.00 \%$ & $73.00 \%$ \\
\hline $49.00 \%$ & $25.00 \%$ & $11.00 \%$ & $15.00 \%$ & $40.00 \%$ & $60.00 \%$ \\
\hline $27.00 \%$ & $15.00 \%$ & $8.00 \%$ & $7.00 \%$ & $65.00 \%$ & $78.00 \%$ \\
\hline $31.80 \% \pm 10.18$ & $20.40 \% \pm 4.56$ & $10.80 \% \pm 2.16$ & $10.20 \% \pm 3.42$ & $57.40 \% \pm 10.31$ & $69.40 \% \pm 7.02$ \\
\hline \multicolumn{6}{|c|}{ MANN WHITNEY U TEST } \\
\hline \multicolumn{2}{|c|}{$\mathrm{U}$ calc $=2 *$} & \multicolumn{2}{|c|}{$\mathrm{U}$ calc $=10.5$} & \multicolumn{2}{|c|}{$\mathrm{U}$ calc $=3.5^{*}$} \\
\hline \multicolumn{2}{|c|}{$\mathrm{P}[\mathrm{u}]=0.016$} & \multicolumn{2}{|c|}{$\mathrm{P}[\mathrm{u}]=0.345$} & \multicolumn{2}{|c|}{$\mathrm{P}[\mathrm{u}]=0028$} \\
\hline \multicolumn{6}{|c|}{ DAY 7 AFTER SURGERY } \\
\hline $18.40 \%$ & $0 \%$ & $4.20 \%$ & $5.00 \%$ & $77.40 \%$ & $95.00 \%$ \\
\hline $11.40 \%$ & $2.05 \%$ & $2.00 \%$ & $4.00 \%$ & $86.60 \%$ & $93.95 \%$ \\
\hline $16.80 \%$ & $1.00 \%$ & $2.80 \%$ & $4.80 \%$ & $80.04 \%$ & $94.20 \%$ \\
\hline $20.60 \%$ & $0 \%$ & $3.40 \%$ & $6.70 \%$ & $76.00 \%$ & $93.30 \%$ \\
\hline $13.60 \%$ & $0.70 \%$ & $3.00 \%$ & $3.20 \%$ & $83.40 \%$ & $96.10 \%$ \\
\hline $16.16 \% \pm 3.68$ & $0.75 \% \pm 6.55$ & $3.08 \% \pm 6.55$ & $4.74 \% \pm 6.55$ & $80.76 \% \pm 4.33$ & $94.51 \% \pm 1.07$ \\
\hline \multicolumn{6}{|c|}{ MANN WHITNEY U TEST } \\
\hline \multicolumn{2}{|c|}{$\mathrm{U}$ calc $=0^{* *}$} & \multicolumn{2}{|c|}{$\mathrm{U}$ calc $=3^{*}$} & \multicolumn{2}{|c|}{$\mathrm{U}$ calc $=0^{* *}$} \\
\hline \multicolumn{2}{|c|}{$\mathrm{P}[\mathrm{u}]=0.004$} & \multicolumn{2}{|c|}{$\mathrm{P}[\mathrm{u}]=0.028$} & \multicolumn{2}{|c|}{$\mathrm{P}[\mathrm{u}]=0.004$} \\
\hline
\end{tabular}

$* *=$ Significant for $\mathrm{a} \leq 0.01, *=$ Significant for a $\leq 0.05$.

knowledge of the molecular mechanism of these protections are not known, epidemiological, clinical and experimental studies have addressed this efficacy.

One cup of green gea $(240 \mathrm{ml})$ may contain $400 \mathrm{mg}$ of polyphenolic antioxidants, with up to 200mg of EGCG (Mukhtar \& Ahmad; Chen et al., 2002).
Studies have indicated that frequent consumption of green tea enables the body to maintain a high level of tea polyphenols (Mukhtar \& Ahmad), and that consumption of at least 2 cups of tea per day may reduce the mortality rate by myocardial infarction (Mukamal et al., 2002), and Shirakami et al., showed that not only a high concentration $(0.1 \%=$ about six cups of green tea/day $)$, but also a low 
concentration $(0.01 \%)$ of EGCG may be sufficient to reduce some tumor growth.

Addressing the effects of green tea on wound healing, our study showed that the regular use of green tea significantly improved the initial epithelial neoformation, as can be seen at Table I. On day 3 after surgery, when epithelial neoformation is in the initial phases, the surgical areas presented $48.20 \%$ X $27.32 \%$ epithelial nerformation for the green tea group and their controls respectively. The differences between groups are not so evident at the end of the wound healing process ( 7 days after surgery), however, they are very impressive on day 3 .

The results of the present study along with other information about green tea in the literature, strongly suggests that regular use of green tea may be beneficial in surgery situations where fast epithelial neoformation is desirable.

NEVES, A. L. A.; KOMESU, M. C. \& DI MATTEO, M. A. S. Efectos del uso del té verde sobre la cicatrización. Int. J. Morphol., 28(3):905-910, 2010.

RESUMEN: El té verde, producto de la planta Camellia sinensis, consiste en más de 200 componentes. Los más conocidos son las catequinas o compuestos polifenólicos o flavonoides, pero contiene también polisacáridos conjugados, aminoácidos, cafeína y vitaminas. Diversos estudios han sugerido que el consumo regular de té verde reduce el riesgo de cáncer, protege contra los eventos iniciales y su progresión, puede actuar como antioxidante, tiene propiedades bactericidas, y su consumo puede ser un co-adyuvante en el tratamiento de la diabetes mellitus, hipertensión e hipercolesterolemia. Nuestro estudio experimental fue realizado con ratas Wistar machos, separadas en dos grupos, experimental y control. Los animales del grupo control recibieron agua ad libitum y los animales del grupo experimental recibieron té verde. Después de 2 semanas de experimentación, en todos los animales fueron realizadas heridas quirúrgicas en el dorso. Los animales fueron sacrificados 1, 3 y 7 días después de la cirugía. Muestras de piel fueron usadas para evaluación microscópica. Nuestros resultados permitieron observar que el grupo experimental (tratado con té verde) presentó una aceleración en la neoformación epitelial en el $3^{\text {er }}$ día posquirúrgico, cuando la neoformación está en la fase inicial. En este período, las áreas quirúrgicas presentaron 48,20\% de neoformación epitelial en el grupo tratado contra 27,32\% en el grupo control. Los resultados del presente estudio, junto con otras informaciones existentes en la literatura sobre el té verde, sugieren fuertemente que el uso regular de este producto puede ser benéfico en situaciones quirúrgicas, cuando se desea una rápida neoformación epitelial.

PALABRAS CLAVE: Té verde; Cicatrización; Ratas Wistar.

\section{REFERENCES}

Ahmad, N.; Feyes, D. K.; Nieminem, A. L.; Argawal, R. \& Mukhtar, H. Green tea constituent epigallocatechin-3gallate and induction of apoptosis and cell cycle arrest in human carcinoma cells. J. Nat. Cancer Inst., 89:18816, 1997.

Chalkley, H.W. Method for the quantitative morphologic analysis of tissues. J. Natl. Cancer Inst., 4:47-53, 1943.

Chen, P.C.; Wheeler, D. S.; Milhotra, V.; Odoms, K.; Denenberg, A. G. \& Wong, H. R. A green tea-derived polyphenol, Epigallocatechin-3-Gallate, inhibits IkB kinase activation and IL-8 gene expression in respiratory epithelium. Inflammation, 26(5): 233-41, 2002.

Chen, X.; Ye, Y.; Cheng, H.; Jiang, Y. \& Wu Y. Thermal effects on the stability and antioxidant activity of na acid polysaccharide conjugate derived from green tea. $J$. Agric. Food Chem., 57:5795-8, 2009.

Fujihara, T.; Nakagawa-Izumi, A.; Ozawa, T. \& Numata, O.
High-molecular-weight polyphenols from oolong tea and black tea: purification, some properties, and role in increasing mitochondrial membrane potential. Biosci. Biotechnol. Biochem., 71(3):711-9, 2007.

Fijiki, H. Two stages of cancer prevention with green tea. J. Cancer Res. Clin. Oncol., 125:589-97, 1999.

Jankun, J.; Selman, S. H.; Swiercz, R. \& Skrzypczak-Jankun, E. Why drinking green tea could prevent cancer? Nature, 387:561-5, 1997.

Monobe, M.; Ema, K.; Kato, F. \& Maeda-Yamamoto, M. Immunostimulating activity of a crude polysaccharide derived from green tea (Camellia sinensis) extract. $J$. Agric. Food Chem., 56:1423-7, 2008.

Most, D.; Hoyt, J.; Sibley, R. K. \& Press, B. H. J. Parenchymal cytokine expression precedes clinically observed ischemia in dorsal flaps in the rat. Plast. Reconst. Surg., 98(5):856-61, 1996. 
Mukamal, K. J.; Maclure, M.; Muller, J. E.; Sherwood, J. B. \& Mittleman, M. A. Tea consumption and mortality after acute myocardial infarction. Circulation, 105:2474-9, 2002.

Mukhtar, H. \& Ahmad, N. Green tea in chemoprevention of cancer. Toxicol. Sci., 52:111-7,1999.

Mustoe, T. A.; Pierce, G. F.; Thomason, A.; Gramates, P.; Sporn, M. B. \& Deuel, T. F. Accelerated healing of incisional wounds in rats induced by transforming growth factor-b. Science, 237(4820):1333-6, 1987.

Shirakami, Y.; Shimizu, M.; Adachi, S.; Sakai, H.; Nakagawa, T.; Yasuda, Y.; Tsurumi, H.; Hara, Y. \& Miriwaki, H. (-)-Epigallocatechin gallate suppresses the growth of human hepatocellular carcinoma cells by inhibiting activation of the vascular endothelial growth factor-vascular endothelial growth factor receptor axis. Cancer Sci., 100:1957-62, 2009.

Yang, C. S.; Kim, S.; Yamg, G. Y.; Lee, M. J.; Liao, J.; Chung, J. Y. \& Ho, C. T. Inhibition of carcinogenesis by tea: bioavailability of tea polyphenols and mechanisms of actions. Proc. Soc. Exper. Biol. Med., 220:213-7, 1999.

Yu, R.; Jiao, J. J.; Duh, J. L.; Grudehithlu, K.; Tan, T. H. \& Kong, A. N. Activation of mitogen-activated kinase by green tea polyphenols: Potential signaling pathways in the regulation of antioxidant-responsive elementmediated phase II enzyme gene expression. Carcinogenesis, 18(2):451-6, 1997.

Whitby D. J. \& Ferguson, M. W. Immunohistochemical localization of growth factors in fetal wound healing. Develop. Biol., 147(1):207-15, 1991.
Correspondence to: Marilena Chinali Komesu

Faculdade de Odontologia de Ribeirão Preto - USP

Departamento de Morfologia, Estomatologia e Fisiologia

Via do Café $s / n$ - Campus da USP-RP

Ribeirão Preto-SP

BRAZIL

Fax: (016) 633-0999

Received: 27-08-2009

Accepted: 14-06-2010 